\title{
Hubungan Kebiasaan Belajar Dan Motivasi Berprestasi Dengan Prestasi Belajar PKn
}

\author{
I. M. E Gunawan¹, I. N. Murda²., I. G. Margunayasa³. \\ ${ }^{1}$ Jurusan Pendidikan Dasar, Program Studi Pendidikan Guru Sekolah Dasar, FIP, Universitas Pendidikan Ganesha, Singaraja, Indonesia \\ 2 Jurusan Pendidikan Dasar, Program Studi Pendidikan Guru Sekolah Dasar, FIP, Universitas Pendidikan Ganesha, Singaraja, Indonesia \\ ${ }^{3}$ Jurusan Pendidikan Dasar, Program Studi Pendidikan Guru Sekolah Dasar, FIP, Universitas Pendidikan Ganesha, Singaraja, Indonesia \\ e-mail: made.edi.gunawan@undiksha.ac.id¹ inyoman.murda@undiksha.ac.id², igede.margunayasa@undiksha.ac.id³ $^{3}$
}

\begin{abstract}
Abstrak
Penelitian ini bertujuan untuk mengetahui hubungan yang signifikan antara kebiasaan belajar dan motivasi berprestasi dengan prestasi belajar PKn siswa kelas V SD Gugus I Kecamatan Pupuan Tahun Pelajaran 2018/2019. Jenis penelitian ini adalah penelitian ex post facto dengan analisis regresi sederhana dan regresi ganda. Populasi penelitian ini adalah seluruh siswa kelas V SD Gugus I Kecamatan Pupuan yang berjumlah 118 siswa dengan jumlah sampel 91 siswa. Data penelitian dikumpulkan dengan kuesioner kebiasaan belajar, kuisioner motivasi berprestasi dan pencatatan dokumen untuk data prestasi belajar PKn. Hasil penelitian menunjukkan bahwa: 1) terdapat hubungan yang positif dan signifikan antara kebiasaan belajar dengan prestasi belajar PKn, dengan koefisien korelasi sebesar 0,$671 ; 2$ ) terdapat hubungan yang postif dan signifikan motivasi berprestasi dengan prestasi belajar PKn, dengan koefisien korelasi sebesar 0,660; dan 3) secara bersama-sama terdapat hubungan yang positif dan signifikan antara kebiasaan belajar dan motivasi berprestasi dengan prestasi belajar PKn, dengan koefisien korelasi sebesar 0,658. Berdasarkan hasil penelitian, disimpulkan bahwa kebiasaan belajar dan motivasi berprestasi berhubungan dengan prestasi belajar PKn siswa.
\end{abstract}

\begin{tabular}{l} 
Keywords: \\
\hline Kebiasaan belajar, \\
motivasi berprestasi, \\
prestasi belajar PKn
\end{tabular}

\section{Pendahuluan}

Pendidikan merupakan salah satu usaha manusia dalam menumbuhkan dan mengembangkan potensi diri baik secara jasmani maupun rohani yang sesuai dengan nilai-nilai yang ada di masyarakat dan budaya (Arfani, 2016).Kemajuan suatu bangsa atau negara juga tidak lepas dari pendidikannya karena pendidikan memiliki peranan yang penting dalam meningkatkan SDM atau sumber daya manusia. Sekolah menjadi salah satu lembaga pendidikan yang formal diselenggarakan oleh pemerintah untuk mewujudkan pendidikan nasional (Setyowati, 2016). Cara untuk mencapai tujuan tersebut dengan melalui interaksi di dalam proses belajar di sekolah, sistematik dan juga terarah menuju ke arah perubahan tingkah laku setiap anak didik yang sesuai dengan yang diharapkan.

Pelaksanaan pendidikan nasional harus menjamin peningkatan mutu pendidikan ditengah pengaruh global agar setiap warga Indonesia menjadi makhluk yang patuh terhadap Tuhan Yang Maha Esa, memiliki akhlak yang mulia, cerdas, proaktif dan berdaya saing tinggi baik di pergaulan nasional maupun di dalam pergaulan internasional. Pendidikan dasar memiliki fungsi yang sangat penting yang pada dasarnya memiliki dua fungsi utama. Pertama, memberikan pendidikan dasar yang terkait dengan kemampuan berpikir kritis, membaca, menulis, berhitung penguasaan dasardasar untuk mempelajari saintek, dan kemampuan berkomunikasi yang merupakan tuntutan kemampuan minimal dalam kehidupan masyarakat.Kedua, pendidikan dasar memberikan dasardasar untuk mengikuti pendidikan pada jenjang berikutnya (Bhoke, 2017). Disamping itu 
pendidikan dasar memegang peranan sangat penting dalam pembentukan kepribadian siswa baik secara internal maupun eksternal, salah satu mata pelajaran dalam membentuk kepribadian siswa adalah mata pelajaran Pendidikan Kewarganegaraan (PKn).

Pendidikan Kewarganegaraan adalah mata pelajaran yang berkaitan dengan afektif untuk mengembangkan dan melestarikan nilai luhur dan moral bangsa dan memfokuskan pada pembentukan warganegara dan mampu melaksanakan hak dan kewajiban untuk menjadi warga negara yang cerdas, terampil dan berkarakter (Husni, dkk, 2013). Pendidikan Kewarganegaraan (PKn) memiliki peranan yang strategis dan penting, yaitu dalam membentuk siswa maupun sikap dalam berperilaku keseharian, sehingga diharapkan setiap individu mampu menjadi pribadi yang baik. Dorongan belajar siswa pada bidang pelajaran PKn ini perlu mendapat perhatian khusus karena dorongan untuk belajar merupakan salah satu faktor penunjang keberhasilan proses belajar. Disamping itu dorongan juga timbul darikebutuhan siswa yang merupakan faktor penting bagi siswa dalam melaksanakan kegiatan-kegiatan atau usahanya.

Pembelajaran PKn di SD sudah berjalan dengan baik, namun ada beberapa siswa yang masih kurang suka dengan pelajaran PKn. Beberapa fakta membuktikan siswa SD kurang suka dengan mata pelajaran Pendidikan Kewarganegaraan (PKn) yaitu pada saat wawancara pada tanggal 14 Januari 2019 dengan beberapa siswa kelas V di beberapa SD Gugus 1 Kecamatan Pupuan, alasan siswa sangat beragam, ada beberapa siswa yang mengatakan tidak suka dengan mata pelajaran ini karena materinya susah dimengerti dan dipahami, selalu berganti mengikuti perkembangan zaman, membuat siswa menjadi mengantuk saat pelajaran. Namun, beberapa fakta juga membuktikan bahwa siswa SD menyukai pelajaran PKn. Beberapa siswa menganggap mata pelajaran PKn sangat penting karena pelajaran tersebut mengajarkan nilai-nilai moral kepada warga negara serta penerapannya di dalam masyarakat. Mata pelajaran ini juga dianggap mudah karena bukan mata pelajaran yang menuntut teori saja, namun bisa menggunakan logika sesuai jawaban yang tetap rasional. Mempelajari PKn membuat para siswa tahu mengenai tata cara kehidupan bernegara dengan baik dan menjadi warga negara Indonesia yang taat dan patuh terhadap aturan yang ada di Indonesia.

Pada saat pembelajaran PKn sedang berlangsung siswa mengatakan bahwa, siswa merasa takut salah atau takut ditertawakan dalam mengajukan pertanyaan padahal ada beberapa materi yang belum dimengerti, siswa takut untuk menjadi unggul dari temannya dan hanya mengandalkan siswa yang mendapatkan juara dikelas untuk menjawab pertanyaan yang diajukan oleh guru, dan siswa merasa bosan untuk belajar sehingga untuk menghilangkan kebosanan tersebut siswa mengganggu temannya. Pada saat dirumah sebagian besar siswa mengatakan bahwa, siswa hanya belajar saat menjelang ulangan saja, dan siswa belajar dirumah hanya 30 menit saja, itupun siswa belajar karena dipaksa orang tuanya.Beberepa siswa juga sudah belajar sesuai jadwal yang ditetapkan. Guru kelas V mengatakan bahwasiswa malas membaca buku dan membuat catatan,siswa membaca dan membuat catatan jika disuruh. Beberapa siswa lebih banyak bermain di rumah danada beberapa siswa yang tidak mengerjakan tugas.Selain itu siswa kurang percaya diri dalam mengajukan pertanyaan maupun pendapat, siswa juga kurang semangat untuk mengikuti pelajaran, dan didalam menjawab pertanyaan yang diajukan oleh guru, siswa yang mengacungkan tangan dan menjawab hanya siswa yang mendapatkan juara di kelas.

Hasil obervasi yang dilakukan tanggal 14 Januari 2019 pada saat pembelajaran sedang berlangsungdiperoleh informasi seperti siswa tidak memperhatikan saat guru sedang menjelaskan materi pelajaran PKn disebabkan siswa bosan dan jenuh dengan cara guru menerangkan kepada siswa tersebut sehingga siswa lebih memilih mengobrol dan bermain dengan teman sebangku dari pada memperhatikan guru yang sedang menjelaskan materi tetapi sebagian siswa sudah fokus dan memperhatikan guru pada saat menjelaskan materi. Selain bosan, sebagian siswa juga kurang mengerti dan guru harus mengulang kembali pelajaran yang sudah diajarakan itu dikarenakan siswa kurang termotivasi dalam belajar sehingga siswa tidak terbiasa umtuk belajar dirumah tentang materi apa yang akan diajarkan besok oleh gurunya. Dan pada saat ada pertanyaan diajukan oleh guru, siswa yang menjawab hanya siswa-siswa yang mendapat juara dikelas saja. 
Melengkapi hasil wawancara dan observasi maka dilanjutkan dengan studi dokumentasi yang dilakukan pada tanggal 14 Januari 2019. Diperoleh bahwa prestasi belajar siswa terbilang bagus, namun ada beberapa siswa yang mendapat nilai dibawah nilai KKM pada mata pelajaran PKn. Hal ini dapat dilihat dari rata - rata nilai semester ganjil. Data yang dimaksud dapat dilihat pada Tabel 1.

Tabel 1.

Nilai Rata - rata Semester Ganjil Pelajaran PKn Kelas V SD Gugus I Kecamatan Pupuan Tahun Ajaran 2018/2019

\begin{tabular}{|c|c|c|c|c|c|c|}
\hline \multirow[b]{2}{*}{ No } & \multirow[b]{2}{*}{ Sekolah } & \multirow[b]{2}{*}{$\begin{array}{l}\text { Nilai Rata- } \\
\text { rata }\end{array}$} & \multirow[b]{2}{*}{ KKM } & \multicolumn{2}{|c|}{ Jumlah Siswa } & \multirow[b]{2}{*}{$\begin{array}{l}\text { Jumlah } \\
\text { Siswa }\end{array}$} \\
\hline & & & & Tuntas & $\begin{array}{c}\text { Tidak } \\
\text { Tuntas } \\
\end{array}$ & \\
\hline 1 & SD Negeri 1 Pupuan & 78,14 & 74 & 15 & 12 & 27 \\
\hline 2 & SD Negeri 2 Pupuan & 78,17 & 75 & 7 & 10 & 17 \\
\hline 3 & SD Negeri 2 Pajahan & 61,11 & 60 & 7 & 10 & 17 \\
\hline 4 & SD Negeri 3 Pajahan & 77,37 & 70 & 5 & 3 & 8 \\
\hline 5 & SD Negeri 1 Bantiran & 69,03 & 60 & 19 & 7 & 26 \\
\hline 6 & SD Negeri 2 Bantiran & 69,4 & 70 & 5 & 5 & 10 \\
\hline 7 & SD Negeri 3 Bantiran & 77,84 & 70 & 8 & 5 & 13 \\
\hline & $\sum$ & 73,00 & 68,42 & 66 & 52 & 118 \\
\hline
\end{tabular}

Sumber : Guru Kelas V SD Gugus I Kecamatan Pupuan

Berdasarkan tabel tersebut, dapat diketahui bahwa nilai rata-rata semester ganjil pelajaran PKn kelas V SD Gugus I Kecamatan Pupuan tahun ajaran 2018/2019 berkisar antara 61,11-77,84 dengan kategori sedang (Koyan, 2012). Sedangkan dilihat dari nilai KKM maka masih terdapat 52 siswa atau sama dengan 44\% dari jumlah 118 siswa berada di bawah KKM. Hal ini menandakan bahwa hasil belajar PKn siswa masih rendah. Rendahnya hasil belajar PKn siswa dapat disebabkan berbagai permasalahan yang dihadapi siswa tersebut.

Berkaitan dengan prestasi belajar yang merupakan hasil atau bukti usaha yang telah diberikan oleh guru setelah seorang siswa mengikuti pembelajaran dalam kurun waktu tertentu yang mencerminkan hasil belajar. Hasil belajar yang dicapai siswa ini merupakan hasil hubungan antara berbagai faktor yang saling mempengaruhi satu sama lainyaitu faktor internal dan eksternal (Bhoke, 2017). Faktor internal merupakan faktor yang bersumber dari dalam diri siswa, yang mempengaruhi kemampuan belajarnya. Faktor internal ini meliputi: kecerdasan, minat dan perhatian, motivasi, ketekunan, sikap, kebiasaan belajar, serta kondisi fisik diri dan kesehatan. Sedangkan faktor eksternal adalah faktor yang berasal dari luar diri siswa yang mempengaruhi hasil belajar yaitu keluarga, sekolah, dan masyarakat.

Sesuai dengan paparan diatas diduga beberapa faktor internal yang berhubungan erat dengan prestasi belajar siswa, yaitu kebiasaan belajar dan motivasi. Hasil belajar mempunyai hubungan positif dengan kebiasaan belajar karena hasil belajar siswa yang diraih dipengaruhi oleh kebiasaan belajar siswa itu sendiri (Sukmawati, dkk, 2013). Dengan itu dapat diasumsikan bahwa kebiasaan belajar yang baik akan berimbas pada prestasi belajar yang baik juga. Ada beberapa kebiasaan belajar yang mempengaruhi belajar yaitu pembuatan jadwal dan pelaksanaannya, membaca, dan membuat catatan, mengulangi bahan pelajaran, konsentrasi, dan mengerjakan tugas (Slameto, 2013). 
Motivasi juga merupakan faktor yang berhubungan erat dengan prestasi belajar siswa.Motivasi merupakan dorongan yang terdapat dari dalam dan luar diri seseorang/individu untuk berusaha mengadakan perubahan tingkah laku yang lebih baik dalam memenuhi kebutuhannya (Uno, 2016). Kebutuhan yang dimaksud yaitu kebutuhan siswa untuk unggul dari temannya, sehingga siswa akan mendorong dirinya untuk mencapai prestasi yang tinggi yang disebut motivasi bereprestasi. Siswa yang memiliki motivasi berprestasi tinggi dalam kegiatannya akan menetapkan tujuan yang ingin dicapai, menyelesaikan tugas lebih baik, bersedia menyelesaikan tugas yang lebih sulit, bertanggung jawab atas tugas yang diberikan, dan memiliki inisiatif untuk melakukan aktivitas (Hidayah, 2014).

Berdasarkan penelitian yang dilakukan Sukmawati pada tahun 2013 menunjukkan terdapat hubungan yang positif dan signifikan antara kebiasaan belajar siswa dengan korelasi sebesar 0,788.Kebiasaan belajar siswa yang dilakukan siswa mulai dari perencanaan, prosedur belajar, dan strategi belajar dapat meningkatkan prestasi belajar. Berdasarkan penelitian yang dilakukan Dewi pada tahun 2013 juga menunjukkan bahwa terdapat hubungan yang signifikan antara kebiasaan belajar terhadap prestasi belajar siswa dengan korelasi sebesar 0,70.Semakin baik kebiasan belajar siswa, semakin baik pula prestasi belajar siswa tersebut.

Berdasarkan penelitian yang dilakukan Achmad pada tahun 2018 menunjukkan bahwa motivasi berprestasi berkorelasi yang postif terhadap prestasi belajar Fisika dengan korelasi sebesar 0,595 semakin tinggi motivasi berprestasi siswa semakin tinggi pula prestasi belajar siswa. Berdasarkan penelitian Toni pada tahun 2013 juga menunjukkan bahwa terdapat hubungan yang postif dan siginifikan antara motivasi berprestasi terhadap hasil belajar IPA dengan kontribusi sebesar 19\% dan sumbangan efektif sebesar 29,185\%.

Dengan demikian diketahui banyak faktor yang menyebabkan prestasi belajar siswa dalam ranah kognitif tinggi dan juga ada yang masih rendah di sekolah, dua faktor yang menarik perhatian adalah hubungan kebiasaan belajar dan motivasi berprestasi dengan prestasi belajar siswa. Oleh karena itu, kebiasaan belajar dan motivasi berprestasi merupakan faktor yang ikut menentukan prestasi siswa yang berakibat siswa mencapai hasil yang maksimal. Untuk mengetahui bagaimana hubungan yang sebenarnya antara kebiasaan belajar dan motivasi berprestasi terhadap prestasi belajar siswa maka dilakukan penelitian yang berjudul "Hubungan Kebiasaan Belajar dan Motivasi Berprestasi Dengan Prestasi Belajar Mata Pelajaran PKn Kelas V di Gugus I Kecamatan Pupuan".

\section{Metode}

Penelitian ini merupakan penelitian yang menggunakan metode Ex Post Fakto dan jenis penelitian ini adalah penelitian kuantitatif komparatif yaitu suatu metode penelitian yang bertujuan untuk melihat hubungan antara dua variabel atau lebih. Penelitian dilakukan untuk meneliti peristiwa yang telah terjadi dan kemudian melihat kebelakang melalui data-data untuk menemukan faktor-faktor yang mendahului atau menentukan sebab-sebab yang mungkin atas peristiwa yang diteliti. Penelitian ini diarahkan untuk menguji hubungan antara tiga variabel yaitu kebiasaan belajar (X1), motivasi berprestasi (X2) dengan prestasi belajar PKn (Y). Populasi dalam penelitian ini adalah seluruh siswa kelas V SD Gugus I Kecamatan Pupuan tahun Pelajaran 2018/2019 yang berjumalah 118 siswa.

Penelitian ini menggunakan "Proportionate Stratified Random Sampling" yaitu sampel yang memperhatikan perimbangan jumlah siswa kelas dengan perimbangan di SD. Untuk memperoleh data penelitian, penelitian ini menggunakan metode dokumentasi dan metode angket. Metode dokumentasi digunakan untuk memperoleh data tentang hasil belajar Matematika siswa kelas V SD Gugus I Kecamatan Pupuan tahun Pelajaran 2018/2019. Metode angket adalah sebuah pertanyaan maupun pernyataan tertulis yang yang berjumlah 30 pernyataan untuk kebiasaan belajar dan 28 pernyataan untuk angket motivasi berprestasi. Kategori penskoran untuk alternatif jawaban angket kebiasaan belajar (X1) dan motivasi berprestasi (X2) diadopsi dari skala likert. 
Angket yang digunakan adalah angket tertutup yaitu angket yang disajikan dalam bentuk daftar pernyataan yang memiliki alternatif jawaban sehingga responden diminta untuk mengisi jawaban sesuai dengan pendapatnya sendiri dengan cara memberi tanda centang $(\sqrt{ })$.Sebelum instrument ini digunakan untuk pengambilan data penelitian, terlebih dahulu dilakuakan pengujian instrument untuk mengetahui instrument tersebut layak digunakan atau tidak, syarat instrument yang layak digunakan adalah instrument harus valid dan reliabel. Instrumen yang valid berarti alat ukur yang digunakan untuk mendapatkan data (mengukur) itu valid. Validitas adalah suatu ukuran yang menunjukkan tingkat-tingkat kevalidan suatu instrumen.

Suatu instrument yang valid mempunyai validitas tinggi. Sedangkan Instrumen yang reliabel adalah instrumen yang tetap, dapat dipercaya, dan bila digunakan beberapa kali untuk mengukur objek yang sama, akan menghasilkan data yang sama. (Arikunto, 2014 :221). Analisis yang digunakan dalam penelitian ini yaitu analisis deskriptif dan analisisi inferensial. Analisis deskriptif yaitu data dianalisis dengan memaparkan rara-rata (mean), median, modus, dan standar deviasi. Analisis deskriptif ini dilakukan untuk mengetahui tinggi rendahnya kebiasaan belajar, motivasi berprestasi dan prestasi belajar PKn. Analisis inferensial yang digunakan dalam penelitian ini terdiri dari uji prasyarat analisis dan uji hipotesis.

\subsection{Uji Prasyarat Analisis}

Uji prasyarat analisis atau uji asumsi klasik digunakan untuk menguji apakah data yang telah didapatkan memenuhi persyaratan untuk analisis dengan teknik yang telahditetapkan.Terkait dengan hal ini maka uji prasyarat analisis yang digunakan dalam penelitian yaitu: Uji Normalitas, Uji Linearitas, dan Uji Multikolinearitas.

Uji normalitas dimaksud untuk memperlihatkan bahwa data sampel berasal dari populasi yang berdistribusi normal. Dalam uji normalitas dalam penelitian ini, menggunakan teknik Kolmogorov - Smirnov dengan bantuan program SPSS 25. Pengambilan keputusan dari uji normalitas adalah: jika signifikasi $>0,05$ maka data berdistribusi normal begitu sebaliknya jika signifikasi $<0,05$ maka data tidak berdistribusi normal.

Uji linieritas data dilakukan untuk mengetahui bentuk hubungan antara variabel bebas dan variabel terikat yang terdiri dari variabel bebas yaitu kebiasaan belajar $\left(X_{1}\right)$, motivasi berprestasi $\left(X_{2}\right)$, dan variabel terikat yaitu prestasi belajar PKn (Y). Uji liniearitas pada penelitian ini dilakukan dengan bantuan program SPSS 25. Pengambilan keputusan dari uji linieritas adalah: jika nilai signifikasi (deviation from linearity) > 0,05, maka terdapat hubungan yang linier antara variabel bebas dan variabel terikat. Jika nilai signifikasi (deviation from linearity) $<0,05$, maka tidak terdapat hubungan yang linier antara variabel bebas dan variabel terikat.

Uji multikolinieritas digunakan untuk mengetahui apakah terdapat hubungan/korelasi yang cukup tinggi antar variabel bebas. Jika terdapat korelasi yang tinggi, berarti ada aspek yang cukup tinggi antar variabel bebas. Jika terdapat korelasi yang tinggi, berarti ada aspek yang sama diukur pada variabel bebas. Hal ini tidak layak digunakan untuk menentukan bersama-sama variabel bebas terhadap variabel terikat.

Uji multikolinieritas dilakukan dengan uji regresi dengan bantuan SPSS 25 dan berpatokan pada nilai VIF (varians inflation faktor) dan korelasi antar variabel bebas (Sudarmanto, 2013). Kriteria yang digunakan yaitu ; Apabila harga koefisien VIF hitung pada Collinearity Statistics sama dengan atau lebih kecil daripada 10 (VIF hitung < 10), maka Ho diterima yang berarti tidak terdapat hubungan antarvariabel independen (tidak terjadi gejala multikolinieritas), dan sebaliknya apabila harga koefisien VIF hitung pada Collinearity Statistics lebih besar daripada 10 (VIF hitung > 10), maka Ho ditolak yang berarti terdapat hubungan antarvariabel independen (terjadi gejala multikolinieritas).

2.2 Uji Hipotesis

Pengujian hipotesis dilakukan sebagai upaya untuk mencapai tujuan penelitian yang dirumuskan. Maka teknik analisis data yang digunakan dalam penelitian ini adalah analisis regresi sederhana dan regresi ganda dengan bantuan SPSS 25. Uji Hipotesis dalam model regresi ini 
melibatkan 3 hipotesis. Uji hipotesis pertama dan kedua menggunakan uji regresi sederhana, dan untuk uji hipotesis ketiga menggunakan uji regresi ganda.

Uji regresi linier sederhana digunakan untuk memprediksi hubungan antara variabel $\mathrm{X}$ dengan variabel Y. Pada penelitian ini digunakan untuk memprediksi (1) hubungan antara kebiasaan belajar dan prestasi belajar PKn, dan (2) hubungan antara motivasi berprestasi dan prestasi belajar PKn. Uji regresi sederhana dilakukan dengan bantuan SPSS 25 dan persamaan regresi sabagai berikut.

$$
\begin{aligned}
& \text { Y = a + bX (Koyan, 2012) } \\
& \text { Keterangan: } \\
& \begin{array}{ll}
\text { Y } & \text { Variabel terikat } \\
\mathrm{X} & =\text { Variabel bebas } \\
\text { a dan b } & =\text { Konstanta }
\end{array}
\end{aligned}
$$

Konstanta $a$ dan $b$ dalam regresi dapat dilihat pada output SPSS 25 pada tabel Coefficient. Menyatakan besar kecilnya sumbangan variabel $X$ terhadap variabel $Y$ dapat ditentukan dengan nilai $R$ Square pada tabel Model Summary di output SPSS 25 kemudian dikalikan dengan $100 \%$.. Untuk menentukan koefisien korelasi hubungan dengan melihat nilai R pada tabel Model Summary di output SPSS 25 kemudian dikonsultasikan dengan tabel interpretasi nilai r pada Tabel 2.

Tabel 2

Tabel Interpretasi Nilai $r$

\begin{tabular}{ll}
\hline Interval Koefisien & Tingkat Hubungan \\
\hline $0,80-1,000$ & Sangat Kuat \\
$0,60-0,79$ & Kuat \\
$0,40-0,59$ & Cukup Kuat \\
$0,20-0,39$ & Rendah \\
$0,00-0,19$ & Sangat Rendah \\
\hline
\end{tabular}

Uji regresi linier ganda digunakan untuk memprediksi hubungan antara dua prediktor dan satu kriterium. Pada penelitian ini digunakan untuk memprediksi hubungan antara kebiasaan belajar dan motivasi berprestasi dengan prestasi belajar PKn. Uji regresi ganda dilakukan dengan bantuan SPSS 25 dan persamaan regresi sebagai berikut.

$$
\begin{array}{ll}
\mathrm{Y}=\mathrm{a}+\mathrm{b}_{1} \mathrm{X}_{1}+\mathrm{b}_{2} \mathrm{X}_{2} & \text { (Koyan, 2012) } \\
\text { Keterangan: } & \\
\mathrm{Y} & =\text { Variabel terikat } \\
\mathrm{X}_{1} \text { dan } \mathrm{X}_{2} & =\text { Variabel bebas } \\
\mathrm{a}, \mathrm{b}_{1}, \text { dan } \mathrm{b}_{2} & =\text { Konstanta }
\end{array}
$$

Konstanta $a$ dan $b$ dalam regresi dapat dilihat pada output SPSS 25 pada tabel Coefficient. Pada uji ini ditentukan juga Sumbangan Efektif (SE) dan Sumbangan Relatif (SR) masing-masing variabel $X$. rumus yang digunakan sebagai berikut.

$$
\operatorname{SE}(X) \%=B_{X} \times r_{x y} \times 100 \%
$$

Keterangan:

$$
\begin{array}{ll}
\mathrm{SE}(\mathrm{X}) \% & =\text { Sumbangan Efektif Variabel } \mathrm{X} \\
\mathrm{B}_{\mathrm{X}} & =\text { Beta Variabel } \mathrm{X} \\
\mathrm{r}_{\mathrm{xy}} & =\text { Nilai koefisien koerelasi }
\end{array}
$$

Nilai $B_{X}$ didapatkan dari nilai Beta pada Tabel Coefficient di output SPSS 25 dan untuk mendapatkan $r_{\mathrm{xy}}$ dapat dilihat nilai korelasi masing-masing variabel $\mathrm{X}$ dengan variabel $\mathrm{Y}$ pada Tabel Correlations. Setelah mencari sumbangan efektif dilanjutkan dengan mencari sumbangan relatif dengan rumus sebagai berikut. 


$$
S R(X) \%=\frac{S E(X) \%}{R^{2}}
$$

Keterangan :

$\mathrm{SR}(\mathrm{X}) \%=$ Sumbangan Relatif

$\mathrm{SE}(\mathrm{X}) \%=$ Sumbangan Efektif

$\mathrm{R}^{2}=$ Efektifitas Regresi

Nilai $\mathrm{R}^{2}$ dapat dilihat pada nilai R Square di Tabel Model Summary pada output SPSS 25. Hipotesis statistik dalam penelitian ini adalah sebagai berikut.
1. $H_{0}=p x_{1} y=0$
$H_{1}=p x_{1} y \neq 0$
2. $H_{0}=p x_{2} y=0$
$H_{0}=p x_{2} y \neq 0$
3. $H_{0}=p x_{1} x_{2} y=0$
$H_{0}=p x_{1} x_{2} y \neq 0$

Keterangan :

$p x_{1} y=$ Koefisien korelasi antara Kebiasaan Belajar terhadap Prestasi Belajar PKn

$p x_{2} y=$ Koefisien korelasi antara Motivasi Berprestasi terhadap Prestasi Belajar PKn

$p x_{1} x_{2} y=$ Koefisien korelasi antara Kebiasaan Belajar dan Motivasi Berprestasi terhadap Prestasi Belajar PKn

\section{Hasil dan Pembahasan}

Berikut ini disajikan secara urut hasil penelitian, meliputi deskripsi umum hasil penelitian, pengujian perasyaratan analisis, uji hipotesis, dan pembahasan yang menjelaskan hubungan kebiasaan belajar dan motivasi berprestasi dengan prestasi belajar PKn. Deskripsi umum hasil penelitian memaparkan rata-rata, median, modus, standar deviasi, varian, minimum, maksimum, dan rentangan. Deskripsi umum ini dikerjakan dengan bantuan program Microsoft Exell 2007. Hasil deskripsi data: (1) prestasi belajar PKn yaitu rentangan skor antara 85 sampai dengan 51, dengan $\mathrm{n}=91$, diperoleh rata-rata sebesar 62,83 , standar deviasi sebesar 18,43, modus sebesar 63,3, median sebesar 66,63, skor maksimum 85, skor minimum 52, dan rentangan 34, (2) kebiasaan belajar yaitu rentangan skor 109 sampai dengan 75 , dengan $n=91$, diperoleh rata-rata sebesar 90,13, standar deviasi sebesar 24,80 modus sebesar 90,35, median sebesar 90,05, skor maksimun 109, skor minimum 75, dan rentangan 35, dan (3) motivasi berprestasi, rentangan skor 106 sampai dengan 72, dengan $n=91$, diperoleh rata-rata sebesar 85,75, standar deviasi sebesar 24,00, modus sebesar 90,8, median sebesar 85,83 , skor maksimun 106, skor minimum 74, dan rentangan 33.

Dalam pengujian prasyaratan analisis yaitu uji normalitas, uji linieritas dan uji multikolinieritas dengan berbantuan program SPSS 25 maka diperoleh hasil pengujian normalitas untuk data kebiasaan belajar siswa menghasilkan nilai Kolmogorov-Smirnov Z yaitu 0,671 dengan signifikansi sebesar 0,759. Angka signifikansi ini lebih besar dari 0,05 $(\mathrm{P}>0,05)$ sehingga dikatakan bahwa data kebiasaan belajar siswa berdistribusi normal. Begitu juga hasil pengujian normalitas untuk data motivasi berprestasi siswa menghasilkan nilai Kolmogorov-Smirnov Z yaitu 0,647 dengan signifikansi sebesar 0,797. Angka signifikansi ini lebih besar dari 0,05 sehingga dikatakan bahwa data motivasi berprestasi siswa berdistribusi normal. Selanjutnya untuk hasil pengujian normalitas data prestasi belajar PKn siswa menghasilkan nilai Kolmogorov-Smirnov Z yaitu 1,309 dengan signifikansi sebesar 0,065. Angka signifikansi ini lebih besar dari 0,05 sehingga dikatakan bahwa data prestasi belajar PKn siswa berdistribusi normal. 
Sedangkan hasil pengujian linieritas dengan melihat nilai F Deviation from Linierity dapat diketahui hasil analisis $\mathrm{X}_{1}$ dan Y pada tabel di atas menunjukkan bahwa harga $F_{\text {hitung }}=1,626$ dengan signifikasi 0,065 (di atas 0,05 ) sehingga harga $F_{\text {hitung }}$ tidak signifikan. Ini berarti bahwa regresi linier. Kemudian untuk hasil $\mathrm{X}_{2}$ dan $\mathrm{Y}$ pada tabel di atas menunjukkan bahwa harga $F_{\text {hitung }}$ $=1,434$ dengan signifikasi 0,134 (di atas 0,05 ) sehingga harga $F_{\text {hitung }}$ tidak signifikan. Ini juga berarti bahwa regresi linier. Dengan kata lain, terdapat hubungan fungsional yang signifikan antara variabel bebas dengan variabel terikat.

Untuk hasil uji multikolinieritas yaitu nilai VIF atau variabel kebiasaan belajar terhadap prestasi belajar PKn siswa adalah 0,994 dan variabel motivasi berprestasi terhadap prestasi belajar PKn siswa adalah 0,994. Dari hasil analisis di atas, nilai VIF dan Tolerance lebih kecil dari 1, hal ini berarti seluruh data bebas dari gejala multikolinieritas, atau dapat disimpulkan tidak terjadi multikolinieritas dan memenuhi uji prasyarat analisis.

Berdasarkan hasil perhitungan menggunakan SPSS 25, didapatkan hasil untuk uji hipotesis yaitu; berdasarkan hasil analisis penelitian menunjukan bahwa terdapat hubungan yang positif dan signifikan antara kebiasaan belajar dan prestasi belajar PKn yang diperoleh siswa sebesar 0,671 yang termasuk dalam kategori kuat kemudian didapatkan nilai konstanta sebesar 14,215 dan nilai koefisien kebiasaan belajar sebesar 0,540 dengan persamaan regresinya yaitu $Y=14,215$ $+0,540 \mathrm{X}$. Dari persamaaan tersebut dijelaskan bahwa koefisien regresi tersebut bernilai positif, sehingga dapat dikatakan bahwa arah hubungan kebiasaan belajar dengan prestasi belajar PKn adalah positif. Untuk nilai $t_{\text {hitung }}$ didapat sebesar 8,527 dengan $t_{\text {tabel }}$ sebesar 1,662 maka dilakukan analisis perhitungan, diperoleh $t_{\text {hitung }}>t_{\text {tabel }}$ atau 8,527 lebih besar daripada 1,662 sehingga nilai $t_{\text {hitung signifikan. }}$

Hal ini menunjukan bahwa kebiasaan belajar memiliki peran yang cukup penting untuk mendapatkan prestasi belajar siswa di SD Gugus I Kecamatan Pupuan. Kebiasaan belajar adalah suatu kegiatan belajar yang biasa dilakukan secara teratur dan berkesinambungan dalam kesehariannya yang bersifat tetap sebagai upaya untuk meningkatkan pengetahuan dan keterampilan dalam diri siswa (Dewi, dkk, 2013). Berdasarkan paparan tersebut, dinyatakan bahwa terdapat hubungan yang signifikan antara kebiasaan belajar dengan prestasi belajar PKn siswa kelas V SD Gugus I Kecamatan Pupuan terbukti dalam penelitian ini.

Berdasarkan hasil penelitian menunjukkan terdapat hubungan positif dan signifikan antara motivasi berprestasi dengan prestasi belajar siswa sebesar 0,660 dan berada dalam kategori kuat kemudian diapatkan nilai konstanta sebesar 20,852 sedangkan nilai koefisien regresi motivasi berprestasi sebesar 0,491 dengan persamaan regresinya yaitu $Y=20,852+0,491 X$, dari persamaaan tersebut dijelaskan bahwa koefisien regresi tersebut bernilai positif, sehingga dapat dikatakan bahwa arah hubungan motivasi berprestasi dengan prestasi belajar PKn adalah positif. Untuk nilai $t_{\text {hitung }}$ di dapat sebesar 8,283 dengan $t_{\text {tabel }}$ sebesar 1,662 maka dilakukan analisis perhitungan, diperoleh $t_{\text {hitung }}>t_{\text {tabel }}$ atau 8,283 lebih besar daripada 1,662 sehingga nilai $t_{\text {hitung }}$ signifikan.

Selain kebiasaan belajar yang harus dimiliki siswa, penting juga siswa harus memiliki motivasi berprestasi. Motivasi berprestasi merupakan suatu dorongan yang berhubungan dengan bagaimana peserta didik melakukan sesuatu dengan lebih cepat, lebih baik, lebih efisien jika dibandingkan dengan apa yang telah peserta didik lakukan sebelumnya, sebagai usaha mencapai keberhasilan atau sukses dalam suatu bidang tertentu dengan suatu taraf keunggulan yang dapat berupa prestasi orang lain maupun prestasi peserta didik sendiri (Achmad, dkk, 2018) . Individu yang memiliki motivasi berprestasi tinggi dalam kegiatannya akan menetapkan tujuan yang ingin di capai, menggunakan keterampilan dan kemampuan untuk mencapainya. Berdasarkan paparaan tersebut, dinyatakan bahwa terdapat hubungan yang signifikan antara motivasi berprestasi dengan prestasi belajar PKn siswa kelas V SD Gugus I Kecamatan Pupuan terbukti dalam penelitian ini

Pencapaian prestasi belajar yang tidak terlepas dari adanya kebiasaan belajar dan motivasi berprestasi yang tinggi dari siswa, tingginya kedua faktor tersebut tentunya akan berdampak pada prestasi belajar PKn siswa, hal ini berdasarkan hasil analisis regresi ganda yang menunjukan 
bahwa terdapat hubungan yang signifikan antara kebiasaan belajar dan motivasi berprestasi dengan prestasi belajar PKn yang diperoleh siswa sebesar 0,658 yang berarti memiliki nilai hubungan yang kuat dan nilai koefisisen determinasi (R Square) sebesar 0,583 yang berarti secara bersama-sama faktor kebiasaan belajar dan motivasi berprestasi ikut menentukan prestasi belajar PKn sebesar 58,3\% dengan sumbangan efektif dari faktor kebiasaan belajar sebesar $42,27 \%$ dan sumbangan efektif dari faktor motivasi berprestasi sebesar 16,10\%.

Nilai konstanta didapatkan sebesar 25,663 sedangkan nilai koefisien regresi kebiasaan belajar sebesar 0,728 dan koefisien regresi motivasi berprestasi sebesar 0,260 dengan persaman regresinya yaitu $\mathrm{Y}=25,663+0,728 \mathrm{X}_{1}+0,260 \mathrm{X}_{2}$, dari persamaaan tersebut dijelaskan bahwa koefisien regresi tersebut bernilai positif, sehingga dapat dikatakan bahwa arah hubungan kebiasaan belajar dan motivasi berprestasi dengan prestasi belajar PKn adalah positif.. Untuk nilai

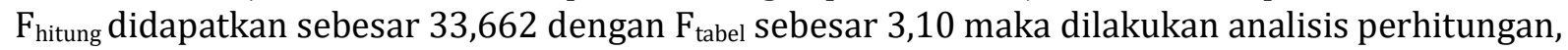
diperoleh $F_{\text {hitung }}>F_{\text {tabel }}$ atau 33,662 lebih besar daripada 3,10 sehingga nilai $F_{\text {hitung signifikan. }}$ Hal ini menunjukan bahwa secara simultan terdapat hubungan yang positif dan signifikan antara kebiasaan belajar dan motivasi berprestasi dengan prestasi belajar siswa di SD Gugus I Kecamatan Pupuan.

\section{Simpulan}

Berdasarkan hasil analisis data dan uji hipotesis serta pembahasan maka dapat diambil kesimpulan sebagai berikut.

1. Terdapat hubungan yang positif dan signifikan antara kebiasaan belajar dengan prestasi belajar PKn siswa kelas V SD Gugus I Kecamatan Pupuan Tahun Pelajaran 2018/2019 dengan $t_{\text {hitung }}$ sebesar 8,527 dan koefisien korelasi R sebesar 0,671 yang berarti memiliki nilai korelasi hubungan yang kuat.

2. Terdapat hubungan yang positif dan signifikan antara motivasi berprestasi dengan prestasi belajar PKn siswa kelas V SD Gugus I Kecamatan Pupuan Tahun Pelajaran 2018/2019 dengan $t_{\text {hitung }}$ sebesar 8,823 dan koefisien korelasi $R$ sebesar 0,660 yang berarti memiliki nilai korelasi hubungan yang kuat.

3. Terdapat hubungan yang positif dan signifikan secara bersama-sama antara kebiasaan belajar dan motivasi berprestasi dengan prestasi belajar PKn siswa kelas V SD Gugus I Kecamatan Pupuan Tahun Pelajaran 2018/2019 dengan nilai $F_{\text {hitung }}$ sebesar 33,662 dan koefisien korelasi R sebesar 0,658 yang berarti memiliki nilai korelasi hubungan yang kuat. Secara bersama-sama faktor kebiasaan belajar dan motivasi berprestasi ikut menentukan prestasi belajar PKn sebesar 58,3\% dengan sumbangan efektif dari faktor kebiasaan belajar sebesar $42,27 \%$ dan sumbangan efektif dari faktor motivasi berprestasi sebesar $16,10 \%$.

Berdasarkan pelaksanaan dan hasil penelitian, berikut ini terdapat beberapa saran yang dapat disampaikan yaitu: Berdasarkan hasil penelitian ini dapat diketahui bahwa kebiasaan belajar dan motivasi berprestasi merupakan karakter yang harus ditumbuhkan dan dimiliki oleh setiap siswa. Oleh karena itu penting bagi guru untuk dapat memperhatikan kebiasaan belajar dan motivasi berprestasi tersebut agar dapat dimiliki oleh siswa sejak dini. Berdasarkan hasil penelitian yang diperoleh dalam penelitian ini yang menunjukan bahwa kebiasaan belajar dan motivasi berprestasi memiliki hubungan dengan prestsi belajar.Namun masih perlu di tingkatkan kembali. Oleh karena itu peneliti selanjutnya perlu memperhatikan faktor lain yang dapat mempengaruhi prestasi belajar siswa dan peneliti lain juga harus lebih melakukan pendekatan ke tiap-tiap sekolah serta lebih memperhatikan instrument dan alat ukur yang dipakai dalam penelitian.

\section{Daftar Pustaka}

Achmad, R.I.,dkk. 2018. "Hubungan Antara Motivasi Berprestasi Dan Kebiasaan Belajar Terhadap Prestasi Belajar Fisika", Prosiding, Volume 3, No 1, (hlm 1-11). 
Agung, A.A.G.2016. Statistika Dasar untuk Pendidikan.Yogyakarta: Deepublish CV Budi Utama.

Arikunto, S. 2013. Prosedur Penelitian Suatu Pendekatan Praktik .Jakarta: Rineka Cipta.

Bhoke,W. 2017. "Hubungan Antara Motivasi Berprestasi Dengan Hasil Belajar Matematika Pada Siswa Kelas IV Sd Gugus V Kecamatan Mauponggo Kabupaten Nagekeo Tahun Ajaran 2015/2016", Jurnal Ilmiah Pendidikan Citra Bakti, Volume 4, No 1, (hlm 29-43).

Dewi, dkk. 2013. "Kontribusi Kebiasaan Belajar Dan Konsep Diri Terhadap Prestasi Belajar Siswa Kelas Iv Di Sekolah Dasar Inti Kecamatan Jembrana", MIMBAR PGSD Undiksha, Volume 1, No 1, (hlm 1-11).

Husni, M., dkk. 2013. "Pengaruh Model Pembelajaran Kooperatif Tipe Think Pair Share terhadap Prestasi Belajar PKN Kelas IV SD Gugus I Selong Ditinjau dari Motivasi Belajar", PENDASI: Jurnal Pendidikan Dasar Indonesia, Volume 3, No 1, (hlm 1-10).

Koyan, I.W. 2012.Statistik Pendidikan Teknik Analisis Data Kuantitatif. Singaraja: Universitas Pendidikan Ganesha Press.

Rahmawati, F., dkk. 2014. "Hubungan antara Pola Asuh Orang Tua dan Kebiasaan Belajar terhadap Prestasi Belajar Siswa SD Kelas IV Semester Genap di Kecamatan MelayaJembrana", MIMBAR PGSD Undiksha, Volume 2, No 1, (hlm 1-11).

Setyowati, L., 2016. Analisis motivasi berprestasi siswa kelas V SD Negeri Slerok 4 Kota Tegal., Jurusan Pendidikan Guru Sekolah Dasar, Universitas Negeri Semarang.

Slameto. 2003. Belajar dan Faktor - faktor yang Mempengaruhinya. Jakarta. PT Rineka Cipta.

Sudarmanto, 2013. STATISTIK TERAPAN BERBASIS KOMPUTER Dengan Program IBM SPSS Statistics 19. Jakarta: Mitra Wacana Media.

Sukmawati, N.P.F., dkk. 2013. "Hubungan antara Efikasi Diri dan Kebiasaan Belajar terhadap Prestasi Belajar Siswa Kelas V SDN di Kelurahan Kaliuntu Singaraja", MIMBAR PGSD Undiksha, Volume 1, No 1, (hlm 1-12).

Toni, I.W.K., dkk. 2013. "Determinasi Konsep Diri, Motivasi Berprestasi Dan DisiplinBelajar Terhadap HasilBelajarIPASD Se-Kecamatan Buleleng". PENDASI: Jurnal Pendidikan Dasar Indonesia, Volume 3, No 1, (hlm 1-11).

Uno, 2016. Teori Motivasi \&Pengukurannya. Jakarta: Bumi Aksara. 